\title{
Helicobacter (Campylobacter) pylori and acid peptic diseases
}

\author{
Sigmund KRAjDEN, MD, FRCPC, PHILIP SHERMAN, MD, FRCPC
}

ABSTRACT: Helicobacter pylori is a spiral-shaped Gram-negative bacteria implicated as a cause of histological gastritis, contributing to peptic ulcer disease and perhaps playing a role in gastric cancer in humans. The organism is found worldwide; the prevalence of infection increases with age; and colonization probably persists for life. Diagnostic approaches that have been used include tissue stains, culture of stomach biopsy specimens, labelled-urea breath tests and serology. It is too early to advocate treatment for all infected individuals; the benefits and risks have yet to be carefully studied and assessed. Can J Gastroenterol 1990;4(6):237-242

Key Words: Campylobacter pylori, Gastritis, Gastric cancer, Helicobacter, Peptic ulcer

\section{Helicobacter pylori et les affections gastro-duodénales}

RESUME: Helicobacter pylori est une bactérie Gram négatif en forme de spirale responsable des gastrites histologiques, contribuant aux ulcères gastro-duodénaux et jouant peut-être un rôle dans le cancer de l'estomac chez l'homme. Cet organisme se trouve partout dans le monde; la prévalence de l'infection augmente avec l'âge et la colonisation existe probablement à vie. Les colorants histologiques, la culture des pièces de biopsie de l'estomac, les tests respiratoires et la sérologie figurent parmi les approches diagnostiques. Il serait précoce de recommander le traitement de toutes les personnes infectées, l'étude et l'évaluation attentives des avantages et des risques étant encore à faire.

St Joseph's Health Centre and Hospital for Sick Children, University of Toronto, Toronto, Ontario

Correspondence and reprints: Dr S Krajden, Director of Microbiology, St Joseph's Health Centre, 30 The Queensway, Toronto, Ontario M6R IB5

Received for publication March 15, 1990. Accepted July 31, 1990
URVED OR SPIRAL-SHAPED BAC-
teria have been observed on the gastric mucosa of animals and man for almost a century. Until recently, they were generally viewed as probable contaminants or commensals. Over the past seven years the conditions for successful cultivation have been defined $(1,2)$, and reports of association with active gastritis, duodenal ulcers and gastric ulceration have led to a reconsideration of their role in human disease $(1,3-5)$.

\section{MICROBIOLOGY}

Campylobacter pylori, recently transferred to a separate genus and now known as Helicobacter pylori (6), is a curved S-shaped Gram-negative rod (oxbow shapes are occasionally seen in vitro), $2.5 \mu \mathrm{m}$ long and $0.5 \mu \mathrm{m}$ wide ( 7 ). The organism has a tuft of four to six unipolar sheathed flagella, making it very motile; it uses a 'corkscrew' action to propel itself through highly viscous materials. The cells have smooth surfaces with rounded ends. Biopsy specimens can be transported in sterile 
nonbacteriostatic isotonic saline or $20 \%$ glucose; in the latter solution, organism viability is sustained for $5 \mathrm{~h}$ at $4^{\circ} \mathrm{C}$ (8). Plating should be done as soon as possible onto nonselective chocolate and 5 to $10 \%$ sheep or horse blood agar or, if contamination is a problem, onto a selective medium (eg, Skirrow's) $(2,8,9)$. After three to five days of incubation at $37^{\circ} \mathrm{C}$ in a moist microaerophilic environment (eg, Campypak; Oxoid, Basingstoke, United Kingdom), smooth, convex, circular, greyish, translucent 1 to $2 \mathrm{~mm}$ colonies appear (2). Growth in broth is enhanced by a large surface area with agitation. The organisms are positive for urease, catalase, oxidase, gamma glutamyl and leucine aminopeptidases and hydrogen sulphide; and negative for indole, hippurate and nitrate (2).

For identification purposes, all strains are resistant to nalidixic acid and sensitive to cephalothin by disk diffusion. In vitro, $H$ pylori is susceptible to cephalosporins, bismuth, tetracyclines, chloramphenicol, aminoglycosides, erythromycin, ciprofloxacin, ofloxacin, oxolinic acid, rifampin, metronidazole and the penicillins. It is resistant to vancomycin, trimethoprim-sulfamethoxazole, the $\mathrm{H}_{2}$ blockers cimetidine and ranitidine, antacids, carbenoxalone and sucralfate (10). Recently, a new noncultivatable spiral bacterium has been found in gastric mucosa. While the numbers are small, they seem to be associated with a chronic active type B gastritis. A proposal for their name is Gastrospirillim hominis (11).

\section{EPIDEMIOLOGY}

$H$ pylori has been found in every country studied (12). In Canada and the United States the prevalence of infection increases with chronological age $(2,7,13)$. H pylori infection is rare in asymptomatic children, averages $20 \%$ in healthy young adults, and is seen in $50 \%$ of 50 -year-old subjects. There are also ethnic differences in the prevalence of $H$ pylori colonization of the antrum. As determined by a positive urea breath test, $60 \%$ of asymptomatic middle-aged Chinese are infected with $H$ pylori versus only $24 \%$ of an age-matched North American population (13). There is no gender predilection. H pylori gastritis has been reported in patients with acquired immune deficiency syndrome (AIDS) (14). Person-tó-person transmission may occur $(15,16)$, but this possibility requires further study. One recent study documented patient-to-patient transmission of $H$ pylori via the fibreoptic endoscope (17). The possibility of a natural or experimental model of $H$ pylori infection in monkeys and the gnotobiotic piglet exists $(18,19)$.

\section{PATHOLOGY}

$H$ pylori colonizes native gastric epithelium or the metaplastic gastric epithelium seen in the duodenum adjacent to ulcers, Barrett's esophagus and Meckel's diverticulum. However, two recent reports found that the organism also inhabits subgingival plaque and dental pulp $(20,21)$. Bacterial colonization of the oral cavity and release of viable organisms in saliva may account for some cases of person-to-person transmission and for colonization of antral mucosa in the same patient.

Generally, $\mathrm{H}$ pylori are found within the mucous layer or beneath it adherent to the apical plasma membrane of antral epithelial cells. The organisms appear to congregate preferentially at or near the intercellular junctions and occasionally penetrate the intercellular spaces (22). H pylori are rarely seen intracellularly (22), and then only contained in phagocytic vacuoles. The mucous layer may protect $H$ pylori from gastric acid while the breakdown of urea (via urease production) to the ammonium ion may help to promote the alkaline conditions which are conducive to its survival.

Histologic study reveals a loss of gastric mucus, sporadic epithelial cell necrosis and neutrophil invasion of the epithelial layer associated with acute and chronic inflammatory cells in the lamina propria. With electron microscopy the surface epithelial cells are edematous, degenerated and depleted of mucus granules; there is also a loss of microvilli. In these areas, $H$ pylori attaches to the eukaryotic cell surface at a region of pedestal formation (23). The receptor for $H$ pylori on red blood cells, tissue culture cells, pig stomach and human antrum is a novel glycerolipid (24). Bacterial adhesion may be mediated by cell surface fibrillar protein antigens (adhesins) (25).

There are a number of factors which could account for $H$ pylori-induced damage to gastric tissue (26). These include: interference with gastric mucus production which thereby facilitates injury by gastric acid; ammonia production mediated via the urease released by $H$ pylori, which may damage cells by increasing the back-diffusion of hydrogen ions into mucosal cells (26); and toxins (27). In addition, extracel. lular proteases, phospholipases and lipases may be released by $\mathrm{H}$ pylori and degrade gastric mucus $(28,29)$. Therefore, proteolytic and lipolytic activity of H pylori could damage both elements of mucosal defence, ie, the mucus layer and the cell membranes of the gastric epithelium. However, additional studies confirming this pathogenic mechanism are required (30).

\section{CLINICAL MANIFESTATIONS}

$H$ pylori has been linked to a variety of disease states in humans.

Chronic active (type B) gastritis: $\ln$ creasing evidence suggests that $\mathrm{H}$ pylori is the etiologic agent of type $\mathrm{B}$ gastritis. Chronic active gastritis (symptomatic or asymptomatic) is closely associated with $H$ pylori infection (31-34). The antral mucosa is most often affected. Clearing of the bacteria is usually as. sociated with a normalization in histo. logical findings (35). Experimental self-feeding $(36,37)$ or inadvertent infection with the organisms $(38,39)$ results in typical gastric inflammation.

Autoimmune (type A) gastritis and secondary (eg, Crohn's disease, drug-induced and bile reflux) gastritis are not associated with $H$ pylori infection $(31,32,40,41)$.

Duodenal ulcer disease: The prevalence of $H$ pylori colonization of inflamed antrum in patients with endoscopically proven duodenal ulcers is fairly high (greater than $70 \%$ ), but this may simply reflect the previously recognized close association between duodenal ulcers and antral inflamma- 
tion (42). Indeed, there are a number of discordant facts in the link between duodenal ulcers and infection with $\mathrm{H}$ pylori: the prevalence of $H$ pylori increases with age though duodenal ulcer disease is not predominantly a disease of the elderly; ulcer craters heal even though bacteria persist; acid hypersecretion (Zollinger-Ellison syndrome) leads to duodenal ulcer disease without Hpylori present; and there is no gender predilection for $H$ pylori infection whereas duodenal ulcer disease predominates in males. Therefore, other factors must also contribute to the pathogenesis of duodenal ulcer disease.

Compelling evidence that $H$ pylori infection plays a role in duodenal ulcer disease comes from the data of antimicrobial treatment trials $(43-45)$. Antibiotics, bismuth and $\mathrm{H}_{2}$ antagonists heal duodenal ulcer disease at the same rate; however, when $\mathrm{H}_{2}$ blocker therapy is discontinued, ulcer recurrence is frequent and rapid. When $H$ pylori is cleared with antibiotics and bismuth compounds, duodenal ulcer disease recurrence is significantly reduced 45). Ulcers that do return after antimicrobial therapy is discontinued are associated with recurrent $H$ pylori infection $(43,45)$.

The genesis of duodenal ulcers may require increased exposure to acid in the duodenum leading to formation of metaplastic gastric epithelium (46) which then becomes colonized by $H$ pylori; this causes further inflammation and with further acid contact an ulcer results. Alternatively, Levi et al (47) proposed that $H$ pylori colonization of the antrum results in an inappropriate release of gastrin from $G$ cells in the stomach, excess acid production by parietal cells and duodenal ulceration from delivery of excess acid into the duodenum.

Family members (symptomatic or asymptomatic) of duodenal ulcer patients have a greater prevalence of $\mathrm{H}$ pylori infection (48). These findings suggest person-to-person spread or a common point source of infection. However, bacterial restriction endonuclease digest analysis of the isolates did not reveal identical organisms within families (49).
Benign gastric ulcer: For a number of reasons, $H$ pylori does not appear to be the sole cause of gastric ulcer. The prevalence of $\mathrm{H}$ pylori infection in gastric ulcer is only 60 to $80 \%$. Nonsteroidal anti-inflammatory drugs account for most gastric ulcers and are not associated with an increased frequency of H pylori colonization.

Barrett's esophagus: When gastric epithelium is found in the esophagus, $\mathrm{H}$ pylori can colonize these metaplastic sites (50). However, the clinical importance is not yet clear (51).

Nonulcer dyspepsia: Self-feeding experiments with H pylori causes transient dyspeptic symptoms consistent with nonulcer dyspepsia $(36,37)$. The prevalence of infection with nonulcer dyspepsia is 40 to $60 \%$, which is similar to that found in an age-matched asymptomatic control population. Antimicrobials provide irregular relief of nonulcer dyspepsia symptoms, although the inflammatory reaction is decreased if $H$ pylori is present (52). Currently, therefore, there is no compelling evidence that $H$ pylori is an important causative factor in nonulcer dyspepsia.

Gastric cancer: Chronic gastritis is considered the precursor lesion of gastric carcinoma (53). Whether these lesions progress from superficial active gastritis due to $H$ pylori is not known. Preliminary reports suggest, however, that there is an association between the presence of these organisms and both gastric dysplasia and carcinoma $(54,55)$. In economically advanced countries, infection with $H$ pylori and the development of gastritis usually occurs in middle age (31). However, in other countries infection with $H$ pylori occurs more frequently with onset of colonization at a younger age (56). It is possible that individuals in a population with a high frequency of gastric carcinoma might become infected with $\mathrm{H}$ pylori at an early age.

\section{LABORATORY DIAGNOSIS}

Culture: Culture of biopsies of gastric mucosa will identify $90 \%$ of persons infected. Distribution of infection may be patchy, so cultures should be obtained from at least two antral sites to enhance the recovery of $\mathrm{H}$ pylori. The organism has rarely been isolated from the body of the stomach unless antraltype mucosa is present or there is mucosal inflammation and bacterial colonization of the antrum (57).

Negative cultures can result from inadequate sampling (ie, biopsy of nonantral epithelium), delay in transport of specimens, swallowed topical anesthetic (eg, benzocaine) (58), prior therapy with bismuth compounds or antibiotics, and residual disinfectant (eg, glutaraldehyde) present on the biopsy forceps and biopsy of nongastric epithelium.

$H$ pylori bacteremia has not been described, perhaps because it does not occur or current commercial blood culture systems are inadequate for its detection (59).

Histology: H pylori detected by various tissue stains correlates well with culture results $(32,34)$. Gram stain of 'touch' preparations of biopsies is a rapid and inexpensive approach to diagnosis that correlates well with results of both culture and other stains (60). The bacteria can be detected in tissue with hematoxylin-eosin, Giemsa, acridine orange, crystal fast violet and silver stains such as the Warthin-Starry, Dieterle and modified Steiner methods which facilitate the detection of bacteria especially when present in small numbers. Monoclonal antibodies against $H$ pylori have been used to detect the organism in clinical specimens by the immunoperoxidase technique (61).

Biochemical tests: Tests which assay for preformed bacterial urease permits the rapid detection of $H$ pylori in biopsy samples (62). In these tests tissue is incubated with urea as a substrate and phenol red as a colour indicator of changes in $\mathrm{pH}$. If $\mathrm{H}$ pylori is present in adequate numbers, bacterial urease hydrolyzes the urea, which raises the $\mathrm{pH}$ and changes the phenol red indicator from yellow to pink. Recently, a Minitek (BBL Microbiology Systems, Maryland) urea disk test has been evaluated which is both sensitive and cost effective (63). Slants of Christensen's urea agar or broth can also be used for the detection of urease. Rapid urease tests correlate fairly well 
with other methods of $H$ pylori detection (62); however, the presence of Proteus species as oral contaminants can result in false positive reactions (8).

Noninvasive breath tests: Bacterial urease forms the basis of noninvasive breath tests (13). A test meal is given with ${ }^{13} \mathrm{C}$ or ${ }^{14} \mathrm{C}$-labelled urea to delay gastric emptying. If $\mathrm{H}$ pylori is present in the stomach, the urea is hydrolyzed and radiolabelled carbon dioxide detected in expired breath samples within $1 \mathrm{~h}$.

Serology: Circulating and local antibodies to $H$ pylori have been measured by agglutination, complement fixation and enzyme-linked immunosorbent assay. There is a strong correlation between high serum $\operatorname{IgG}$ and $\lg \mathrm{A}$ antibody levels to $H$ pylori, gastritis and a positive culture $(34,48,64)$. Antibodies can also be detected in gastric juice and saliva.

Although titres of $H$ pylori-specific antibody may decrease after $H$ pylori infection has been eliminated (65), the levels tend to remain elevated for years.

ACKNOWLEDGEMENTS: Philip Sherman is the ectipient of a Career Scientist Award from the Ministry of Health.

\section{REFERENCES}

1. Warren JR, Marshall BJ. Unidentified curved bacilli and gastric epithelium in active chronic gastritis. Lancet $1983 ; i: 1273$.

2. Bohnen J, Krajden S, Anderson JGD, et al. Campylobacter pyloridis associated with acid-peptic disease in Toronto. Can J Surg 1986;29:442-4.

3. Marshall BJ. Campylobacter pyloridis and gastritis. J Infect Dis 1986:153:650-9.

4. Blaser MJ. Helicobacter pylori and the pathogenesis of gastroduodenal inflammation. J Infect Dis 1990;161:626-33.

5. Peterson WL. Peptic ulcer - An infectious disease? West J Med 1990;152:167-71.

6. Goodwin CS, Armstrong JA, Chilvers $\mathrm{T}$, et al. Transfer of Campylobacter pylori and Campylobacter mustelae to Helicobacter gen. nov. as Helicobacter pylori comb. nov. and Helicobacter mustelae comb. nov, respectively, Int J Syst Bacteriol 1989;39:397-405.

7. Goodwin CS, Armstrong JA, Marshall B]. Campylobacter pyloridis gastritis and peptic ulceration. J Clin Pathol 1986:39:353-65.
Therefore, serology indicates present or past infection and is useful for seroprevalence studies $(48,56)$.

\section{TREATMENT}

In vitro susceptibility of $\mathrm{H}$ pylori does not reliably predict efficacy in the eradication of the organism in humans (66). Many single and combination antimicrobial regimens can suppress bacterial growth, but they are less effective in permanently clearing the organism. Fifty to $90 \%$ of culture-positive patients will become culture-negative immediately after treatment with colloidal bismuth and amoxycillin, singly or in combination. However, only $40 \%$ are still culture-negative one month after treatment is discontinued (67). This indicates that relapse or recurrence of infection is common. Restriction endonuclease digest analysis shows that these recurrences are usually due to relapses with the same strain of organism (68). This may in some cases be related to a reservoir of the organism harboured

8. Krajden S, Bohnen J, Anderson J, et al Comparison of selective and nonselective media for recovery of Campylobacter pylori from antral biopsies. J Clin Microbiol 1987;25:1117-8.

9. Goodwin CS, Blincow ED, Warren JR, Waters TE, Sanderson CR, Easton L. Evaluation of cultural techniques for isolating Campylobacter pyloridis from endoscopic biopsies of gastric mucosa. J Clin Pathol 1985;38:1127-31.

10. McNulty CAM, Dent J, Wise R. Susceptibility of clinical isolates of Campylobacter pyloridis to 11 antimicrobial agents. Antimicrob Agents Chemother 1985;28:837-8.

11. McNulty CAM, Dent JC, Carry A, et al. New spiral bacterium in gastric mucosa. J Clin Pathol 1989;42:585-91.

12. Dwyer B, Kaidor J, Tee W, Marakowski E, Raios K. Antibody responses to Campylobacter pylori in diverse ethnic groups. Scand J Infect Dis 1988;20:349-50.

13. Graham DY, Klein PD, Opekun AR, Boutton TW. Effect of age on the frequency of active Campylobacter pylori infection diagnosed by the $\left({ }^{13} \mathrm{C}\right)$ urea breath test in normal subjects and patients with peptic ulcer disease. J Infect Dis 1988;157:777-80.

14. Meiselman MS, Miller-Latchpole R, Christ M, Rendall E. Campylobacter pylori in the acquired immune deficiency syndrome. Gastroenterology in dental plaque and dental pulp $(20,21,69)$, or simply to inhibition without eradication of bacteria from the stomach. Higher doses, repeated or more prolonged courses of single, double or triple antimicrobials (bismuth and two other agents) may eliminate $H$ pylori $(70,71)$. However, such regimens are associated with increased costs and adverse effects including diarrhea and pseudomembranous colitis. Therefore, the benefits versus potential risks must be carefully considered. The development of safe, convenient and effective therapy will facilitate the investigation of the role of $\mathrm{H}$ pylori in gastroduodenal disease. It is important to define which patient populations and disease entities related to $H$ pylori infection will benefit from therapy. Currently, physicians must temper treatment with common sense and not subject individual patients to possibly ineffective or toxic regimens nor encourage the spread of resistance to clinically useful antimicrobial agents.

1988;95:209-12

15. Shames B, Krajden S, Babida C, Gurgis RV, Kurjanczyl L, Penner JL. Investigation of Campylobacter pylori strains isolated from a husband and his wife. In: Megraud F, Lamouliatte H, eds. Gastroduodenal Pathology and Campylobacter pylori. New York: Elsevier Science Publication, 1989:439. 41.

16. Berkowicz J, Lee A. Person-to-person transmission of Campylobacter pylori. Lancet 1987;ii:680-1.

17. Langenberg W, Rauws AJ, Oudbier JH, Tytgat GNJ. Patient-to-patient transmission of Campylobacter pylori infection by fibreoptic gastroduodenoscopy and biopsy. J Infect Dis 1990;101:507-11.

18. Bronsdon MA, Schoenkyecht FD. Campylobacter pylori isolated from the stomach of monkey, Macaca nemestrina. J Clin Microbiol 1988;26:1725-8

19. Krakowka S, Morgan DR, Kraft WG Leunk RD. Establishment of gastric Campylobacter pylori infection in the neonatal gnotobiotic piglet. Infect Immun 1987;55:2789-90.

20. Krajden S, Fuksa M, Anderson J. Examination of human stomach biop. sies, saliva, and dental plaque for Campylobacter pylori. J Clin Microbiol 1989;27:1397-8.

21. Oderda G, Vaira D, Dellolio D, et al 
Can Campylobacter pylori hide in dental plaque. Klin Wochenschr 1989;67(Suppl XVIII):51

22. Hazell SL, Lee A, Brady L, Hennessey W. Campylobacter pylori and gastritis: Association with intercellular spaces and adaptation to an environment of mucus as important factors in colonization of the gastric epithelium. J Infect Dis 1986;153:658-63.

23. Bode C, Malfertheiner P, Ditschuneit H. Pathogenetic implications of ultrastructural findings in Campylobacter pylori related gastroduodenal disease. Scand J Gastroenterol 1988;23(Suppl 142):25-39.

24. Lingwood CA, Law H, Pellizzari A, Sherman P, Drumm B. Gastric glycerolipid as a receptor for Campylobacter pylori. Lancet 1989;ii:238-41.

25. Evans DG, Evans DJ Jr, Moulds JJ, Graham DY. N-acetylneuraminyllactose-binding fibrillar hemagglutinin of Campylobacter pylori: A putative colonization factor antigen. Infect Immun 1988;56:2896-906.

26. Hazell SJ, Lee A. Campylobacter pyloridis urease, hydrogen ion back diffusion and gastric ulcers. Lancet 1986;i:15-7.

27. Leunk RD, Johnson PT, David BC, Kraft WG, Morgan DR. Cytotoxic activity in broth-culture filtrates of Campylobacter pylori. J Med Microbiol 1988;26:93-9.

28. Slomiany BL, Bilski J, Sarosiek J, et al. Campylobacter pyloridis degrades mucin and undermines gastric mucosal integrity. Biochem Biophys Res Commun 1987;144:307-14.

29. Slomiany BL, Kusinathan C, Slomiany A. Lipolytic activity of Campylobacter pylori; effect of colloidal bismuth sub. citrate (De-Nol). Am J Gastroenterol 1989;84:1273-7.

30. Baxter A, Campbell CJ, Cox DM, Grinham CJ, Pendlebury JE.

Proteolytic activities of human Campylobacter pylori and ferret campylobacter-like organism. Biochem Biophys Res Commun 1989;163:1-7.

31. Drumm B, O'Brien A, Cutz E, Sherman P. Campylobacter pyloridisassociated primary gastritis in children. Pediatrics 1987;80:192-5.

32. Drumm B, Sherman P, Cutz E, Karmali M. Association of Campylobacter pylori on the gastric mucosa with antral gastritis in children. N Engl J Med 1987;316:1557-61

33. Gregson DB, Low DE, Cohen MM, et al. The prevalence of Campylobacter pylori gastritis among asymptomatic adults. Can Med Assoc J 1989;140:1449-53.

34. Dooley CP, Cohen H, Fitzgibbons PL, et al. Prevalence of Helicobacter pylori infection and histologic gastritis in asymptomatic persons. N Engl J Med 1989;321:1562-6.

35. Drumm B, Sherman P, Chiasson D, Karmali M, Cutz E. Treatment of Campylobacter pylori-associated gastritis in children with bismuth subsalicylate and ampicillin. J Pediatr 1988;113:908. 12.

36. Marshall BJ, Armstrong JA, McGehie DB, Glancy RJ. Attempt to fulfil Koch's postulates for pyloric Campylobacter. Med J Aust 1985;142:436-9.

37. Morris A, Nicholson G. Ingestion of Campylobacter pyloridis causes gastritis and raised fasting gastric $\mathrm{pH}$. Am J Gastroenterol 1987;82:192-9.

38. Ramsey EJ, Carey KV, Peterson WL, et al. Epidemic of gastritis with hypochlorhydria. Gastroenterology 1979;76:1449-57.

39. Frommer DJ, Carrick J, Lee A, Hazell SL. Acute presentation of Campylobacter pylori gastritis. Am J Gastroenterol 1988;83:1168-71

40. Flejou J-F, Bahame P, Smith AC, Stockbrugger RW, Rode J, Price AB. Pernicious anaemia and Campylobacter-like organisms: Is the gastric antrum resistant to colonization? Gut 1989;30:60-4.

41. Niemelä S, Karttunen T, Heikkilä J, Mäentausta O, Lehtola J. Relationship of Campylobacter pylori and duodenogastric reflux. Dig Dis Sci $1989 ; 34: 1021-4$

42. Schrager J, Spink R, Mitra S. The antrum in patients with duodenal and gastric ulcers. Gut 1967;8:497-508.

43. Marshall BJ, Warren JR, Blincow E, et al. Prospective double-blind trial of duodenal ulcer relapse after eradication of Campylobacter pylori. Lancet 1988;ii:1437-42

44. Lee Fl, Samloff IM, Harriman M. Comparison of tri-potassium di-citrate bismuthate tablet with ranitidine in healing and relapse of duodenal ulcers. Lancet 1985;i:1299-302.

45. Coghlan JG, Gilligan D, Humphries $\mathrm{H}$, et al. Campylobacter pylori and recurrence of duodenal ulcers - A 12-month follow-up study. Lancet 1987;ii:1109. 11.

46. Wyatt J1, Rathbone BJ, Dixon MF, Heatley RV. Campylobacter pyloridis and acid induced gastric metaplasia in the pathogenesis of duodenitis. J Clin Pathol 1987;40:841-8.

47. Levi S, Beardshall K, Haddad G, Playford R, Gliosh P, Calam J. Campylobacter pylori and duodenal ulcers: The gastrin link. Lancet 1989; i:1 167-8.

48. Drumm B, Perez-Perez G, Blaser MJ, Sherman PM. Intrafamilial clustering of Helicobacter pylori infection. N Engl J Med 1990;322:359-63.

49. Simor AE, Shames B, Drumm B, Sherman P, Low DE, Penner JL.
Typing of Campylobacter pylori by bacterial DNA restriction endonuclease analysis and determination of plasmid profile. J Clin Microbiol 1990;28:83-6

50. Talley NJ, Cameron AJ, Shorter RG, Zinsmeister AR, Phillips SF. Campylo. bacter pylori and Barrett's esophagus. Mayo Clin Proc 1988;63:1176-80.

51. Paull G, Yardley JH. Gastric and esophageal Campylobacter pylori in patients with Barrett's esophagus. Gastroenterology 1988;95:216-8.

52. Loffeld RJLF, Potters HUJP, Stobberingh E, Flendrig JA, Van Spreeuwel JP, Arends JW. Campylobacter associated gastritis in patients with non-ulcer dyspepsia: A double blind placebo controlled trial with colloidal bismuth subcitrate. Gut 1989;30:1206-12.

53. Dooley CP, Cohen H. The clinical significance of Campylobacter pylori. Ann Intern Med 1988;108:70-9.

54. Lambert JR, Dunn KL, Eaves ER, Korman MG, Hansky J. Campylobacter pyloridis in diseases of the human upper gastrointestinal tract. Gastroenterology 1986;90:1509. (Abst)

55. Leon-Barua R, Recavarren S, RamerezRamos A, et al. Reversal of gastric mucosal dysplasia associated with Campylobacter pylori using oral bismuth therapy. Gastroenterology 1988;94:A256. (Abst)

56. Megraud F, Brassens-Rabbe MP, Denis F, Belbouri A, Hoa DQ. Seroepidemiology of Campylobacter pylori infections in various population. J Clin Microbiol 1989;27:1870-3.

57. Marshall BJ, McGechie DB, Rogers PA, Glancy RJ. Pyloric campylobacter infection and gastroduodenal disease. Med J Aust 1985;142:439-44.

58. Czinn SJ, Carr HS, Speck WT. Effects of topical anesthetic agents on Campylobacter pylori. J Pediatr Gastroenterol Nutr 1989;9:46-8.

59. Westblom TU, Maclan E, Midkiff BR, Adkins VW, Subik MA. Failure of Campylobacter pylori to grow in commercial blood culture systems. J Clin Microbiol 1988;27:1029-30.

60. Montgomery EA, Martin DF, Peura DA. Rapid diagnosis of Campylobacter pylori by Gram's stain. Am J Clin Pathol 1988;90:606-9.

61. Negrini R, Lisato L, Cavazzini L, et al. Monoclonal antibodies for specific immunoperoxidase detection of Campylobacter pylori. Gastroenterology 1989;96:414-20.

62. McNulty CAM, Dent JC, Uff JS, Gear MWL, Wilkinson SP. Detection of Campylobacter pylori by the biopsy urease test: $\mathrm{An}$ assessment in 1445 patients. Gut 1989;30:1058-62.

63. Sweeney L, Garcia LP, Talbert M, Silverman M, Needham CA. Minitek 
urea disk test, a sensitive and cost-effective method to screen for Campylobacter pylori in gastric biopsies. J Clin Microbiol 1989;27:2684-6.

64. Perez-Perez GI, Dworkin BM, Chodos JE, Blaser MJ. Campylobacter pylori antibodies in humans. Ann Intern Med 1988;109:11-7.

65. Oderda G, Vaira D, Holton J, Ainlay G, Altorc F, Ansaldi M. Amoxycillin plus tinidazole for Campylobacter pylori gastritis in children: Assessment by serum IgG antibody, pepsinogen I and gastrin levels. Lancet 1989;i:690-2.

66. McNulty CAM. The treatment of
Campylobacter-associated gastritis. Am J Gastroenterol 1987;82:245-7.

67. Rauws EAJ, Langenberg W, Houthoff HJ, Zanen HC, Tytgat GNJ. Campylobacter pylori-associated chronic active antral gastritis: A prospective study of its prevalence and the effects of antibacterial and antiulcer treatment. Gastroenterology 1988;94:33-40.

68. Langenberg W, Rauws EAJ, Widjojokusumo A, Tytget GNJ, Zanen HC. Identification of Campylobacter pylori isolates by restriction endonuclease DNA analysis. J Clin Microbiol 1986;24:414-7.
69. Shames B, Krajden S, Fuksa M, Babida $\mathrm{C}$, Penner JL. Evidence for the occurrence of the same strain of Campylobacter pylori in the stomach and dental plaque. J Clin Microbiol 1989;27:2849. 50.

70. Bayerdorffer E, Ottenjann R. The role of antibiotics in Campylobacter pylori associated peptic ulcer disease. Scand J Gastroenterol 1988;23(Suppl 142):93. 100.

71. Rauws FAJ, Tytgat GNJ. Cure of duodenal ulcer associated with eradica. tion of Helicobacter pylori. Lancet 1990;335:1233-5. 


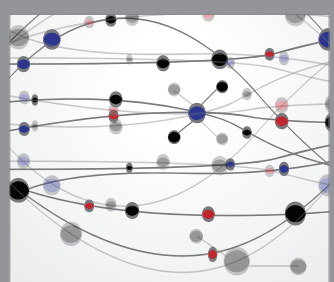

The Scientific World Journal
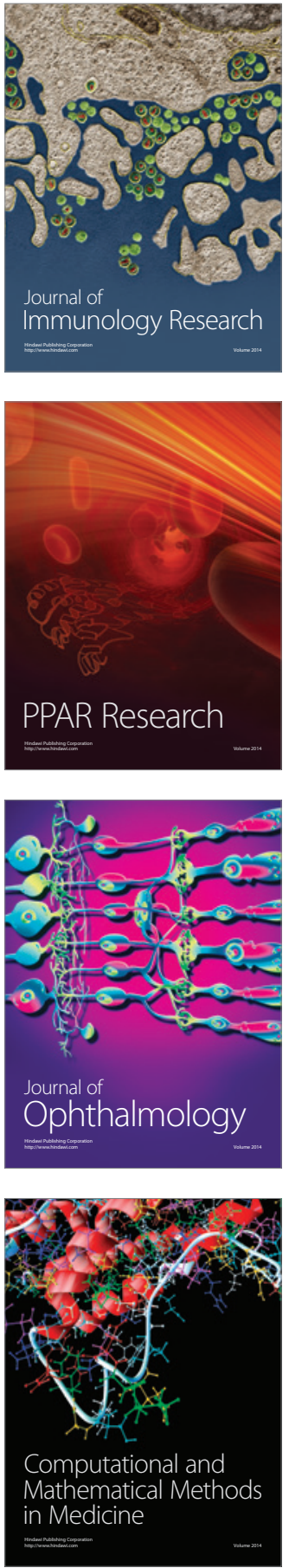

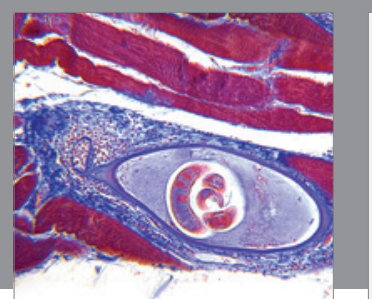

Gastroenterology Research and Practice

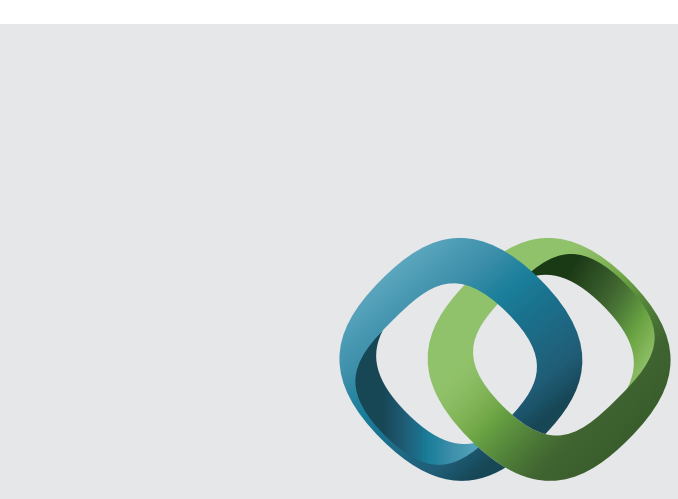

\section{Hindawi}

Submit your manuscripts at

http://www.hindawi.com
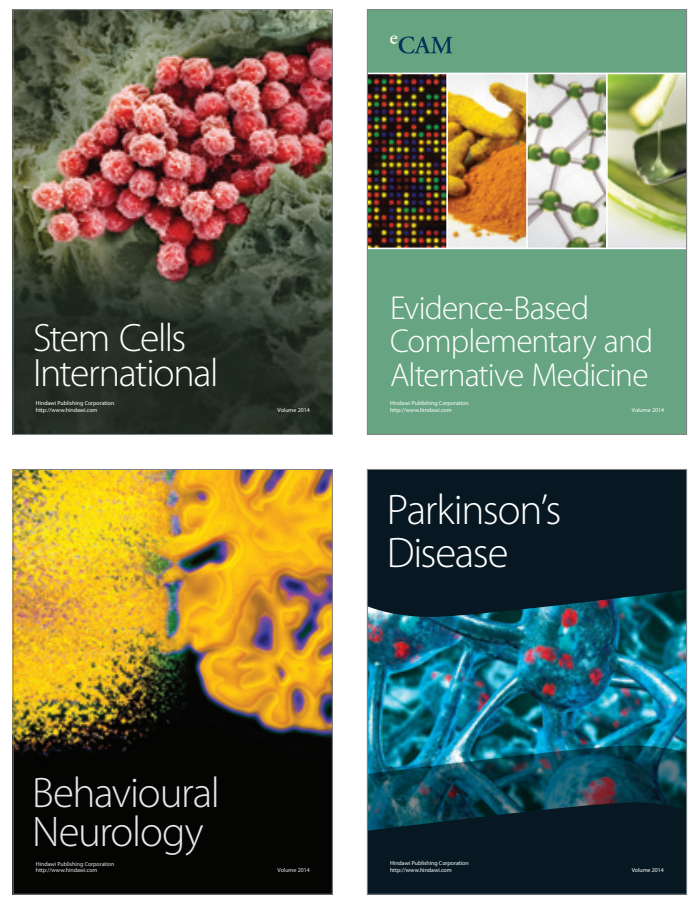
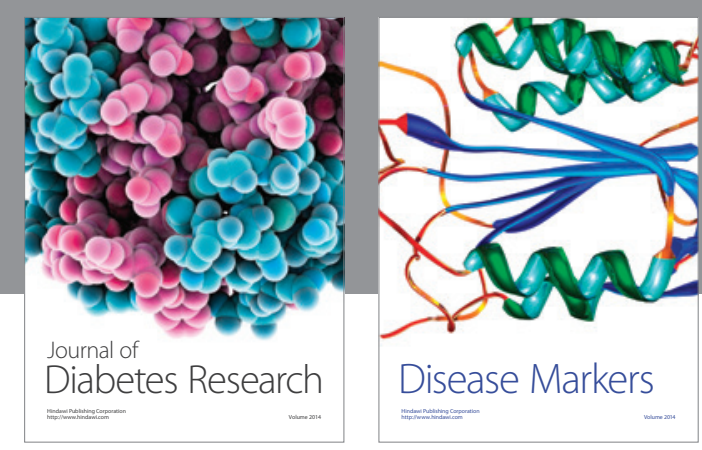

Disease Markers
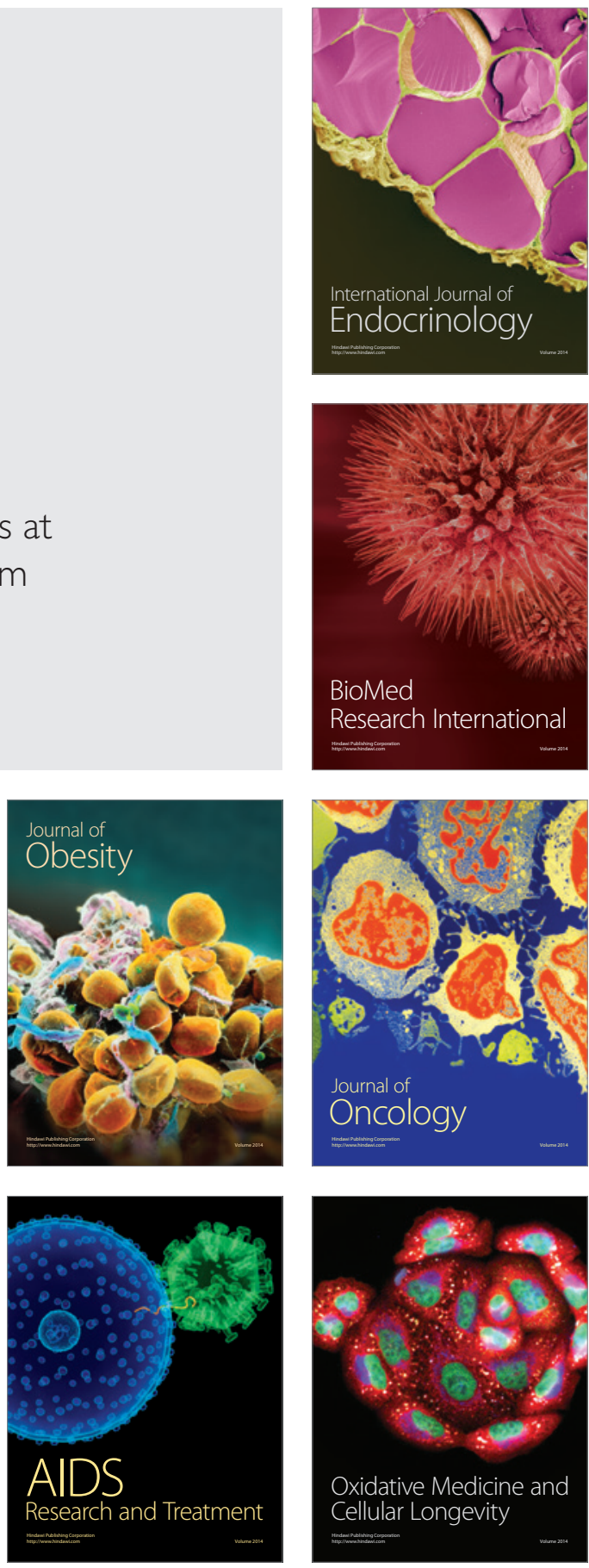